\title{
Ice growth in the presence of an antifreeze protein
}

\author{
Maddalena Bayer-Giraldi, Ilka Weikusat, Cornelia Isert, Sepp Kipfstuhl
}

Antifreeze proteins (AFPs) have evolved in cold-adapted organisms to control ice crystal growth when exposed to sub-zero temperature conditions. It has been suggested that the effect of the proteins results in small ice crystal size, thus avoiding in frozen tissues and cells the damage mechanically caused by large ice grains. Also the polar diatom Fragilariopsis cylindrus, a dominant species within sea-ice assemblages, produces AFPs. We expressed in E. coli a recombinant form of this protein and isolated it by affinity chromatography. We studied its effect on ice grain size after shock-freezing and subsequent annealing, and under slow freezing conditions. Shock-freezing $\left(-40^{\circ} \mathrm{C}\right)$ produced small sized crystals, and during annealing at $-4^{\circ} \mathrm{C}$ AFPs successfully inhibited recrystallization already at low concentrations $(1.2 \mu \mathrm{M})$, as observed at light microscopy and using the Otago optical recrystallometer. However, slow ice growth at $-5^{\circ} \mathrm{C}$, more likely to resemble natural freezing conditions, surprisingly resulted in the formation of larger crystals in the presence of AFPs than in the negative controls. Further characteristic microstructural features, like among others gradual c-axis transition within individual grains and sublimation etching patterns, were observed under crossed polarizers and at light microscopy. These features are possibly due to the incorporation of proteins into the ice lattice during growth, causing local defects.

Our observations remain to be clarified, but should be taken into account when considering the biological role of AFPs as well as potential industrial applications of the proteins. 